DOI: http://dx.doi.org/10.20535/2219-3804162017104901

S. I. Trubachev ${ }^{1}, \mathrm{PhD}$, Associate professor, O. M. Alekseychuk ${ }^{2}, \mathrm{PhD}$, Associate professor

\title{
THE STRESS-STRAIN STATE DETERMINATION IN PIPELINES WELDED JOINTS
}

\begin{abstract}
Ua Визначено напружено-деформований стан у зварних з'єднаннях трубопроводів. Під час досліджень концентрації напружень у зварному шві була використана вісесиметрична розрахункова модель. Отримано залежності розподілу напружень і деформацій у зоні зварювального шва.

Ru Определено напряженно-деформированное состояние в сварных соединениях трубопроводов. При исследовании концентрации напряжений в сварном шве была использована осесимметричная расчетная модель. Получены зависимости распределения напряжений и деформацій в зоне сварного шва.
\end{abstract}

\section{Introduction}

As known, welding structures are widely used in power engineering. Therefore, the problem's solution of a structure's stress-strain state determinination in the weld region is an actual problem. It's connected with changes in material properties, plastic deformation, and overheating [1]. There are three sources of stress concentration for butt weldments: stress concentration as a result of residual strains and stresses during welding, stress concentration determined by the outline of the weld, stress concentration due to displacement of the joined parts.

At present, widespread technique is the method of finite elements [1-3].

\section{Formulation and solution of the problem}

The aim this study is to determine the residual stresses and tensions of the specified load by means of the finite element method.

Let's consider a pipelines butt weld with an external diameter of $300 \mathrm{~mm}$. and a wall thickness of $20 \mathrm{~mm}$. The width of the weld was assumed to be $30 \mathrm{~mm}$. The finite element model is shown in fig. 1. The calculation was carried out using the complex ANSYS, on linear four-node shell finite elements, the number of nodes in the computational model was 1080.

\footnotetext{
${ }^{1}$ National Technical University of Ukraine «Igor Sikorsky Kyiv Polytechnic Institute», department of dynamics and strength of machines and strength of materials

${ }^{2}$ National Technical University of Ukraine «Igor Sikorsky Kyiv Polytechnic Institute», department of theoretical mechanics
} 


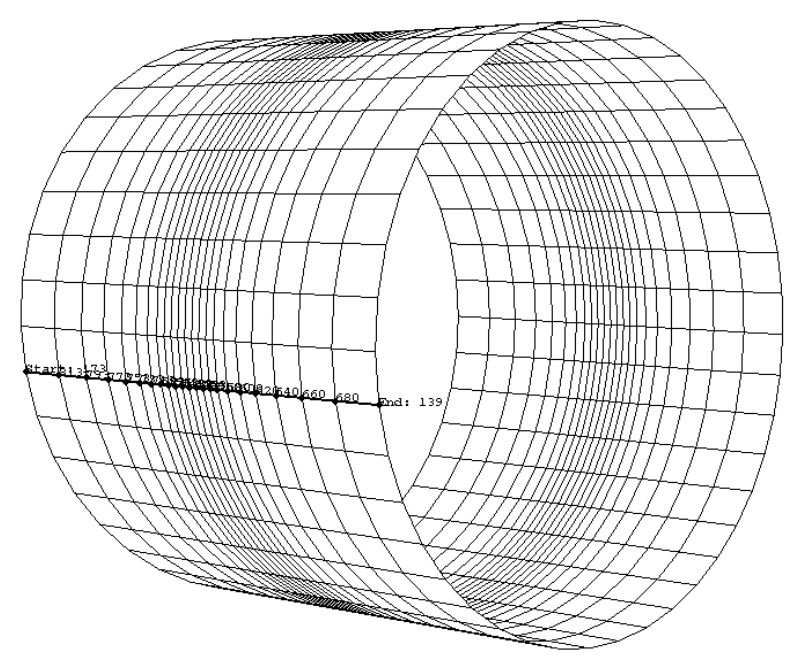

Fig. 1. Finite element pipe model

In the calculation was used the steel with the following properties: Young's modulus E $=2 \cdot 10^{7} \mathrm{M}$ M, Poisson's ratio $\mu=0,3$, relative residual elongation $\delta=0,25$, coefficient of temperature expansion $\alpha=1,210^{-5} 1 /{ }^{\circ} \mathrm{C}$.

Yield point $\sigma_{0,2}$ was taken as a function of temperature in the form shown in Fig. 2.

The Strength limit in the temperature range from 0 to $500^{\circ} \mathrm{C}$ was assumed to be $\sigma_{\mathrm{b}}=420 \mathrm{MPa}$, and it was considered that the material was perfectly plastic at temperatures above $500^{\circ} \mathrm{C}$.

For the entire temperature range, the Mises fluidity condition was used for the material. The material had a linear isotropic hardening at a temperature below $500^{\circ} \mathrm{C}$.

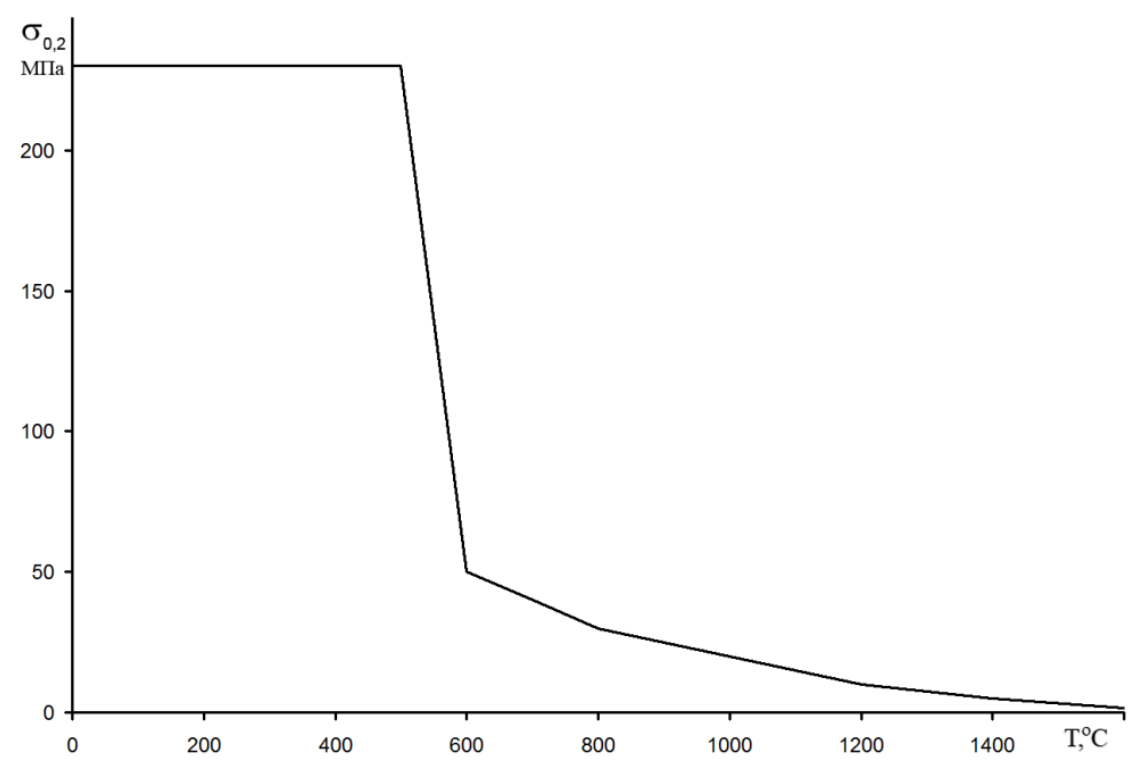

Fig.2. The dependence of yield stress from temperature

To determine the stress-strain state in the zone of the welded seam concentration, a finite-element model was constructed as shown in Fig. 3. Flat four- 
node finite elements were used in the model constructing. The number of model nodes is 624 . Two separate calculations were made: first was a depence from the temperature effect the next was a depence from the action of the tensile stress, that's arising in the tube under the action of internal pressure.

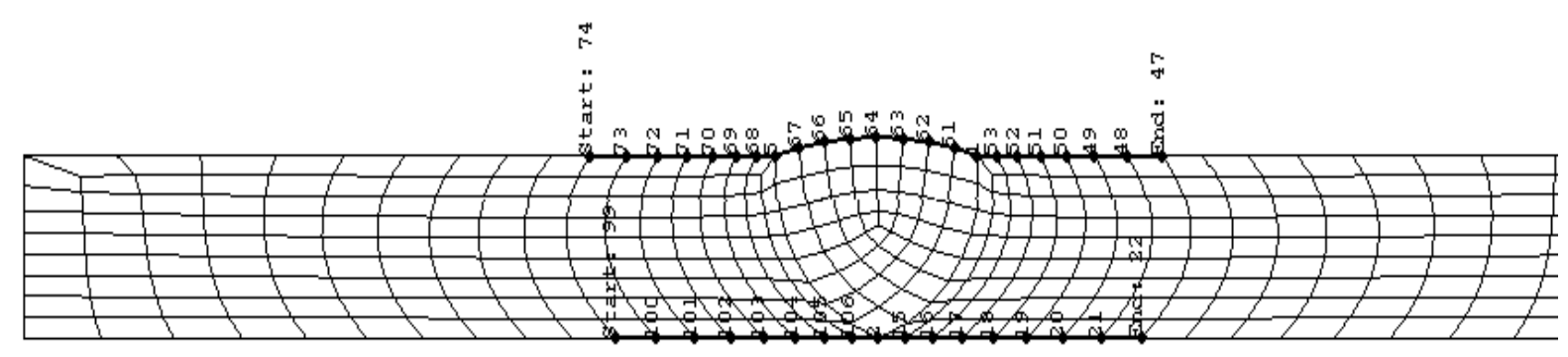

Fig. 3. Finite element model

As a result of the calculation, the distribution of temperature residual stresses in the weld seam was obtained (Fig. 4).
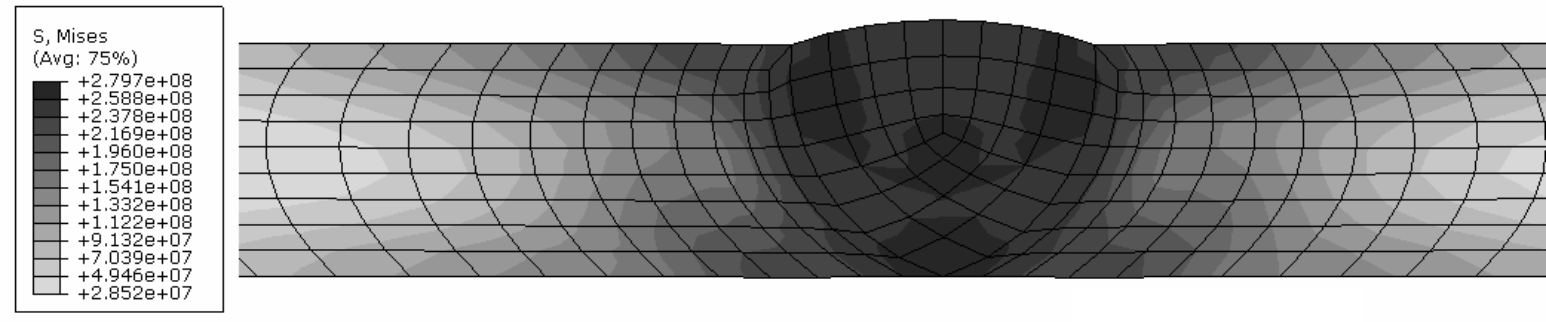

Fig.4. Residual temperature stresses

Stress variation at the edge of the pipe and at the center of the weld seam, depending on the intensity of the applied internal pressure, is shown in Fig. 5.

The change in the plastic deformation along the center of the welded seam, depending on the intensity of the internal pressure in the pipe, is shown in Fig. 6.

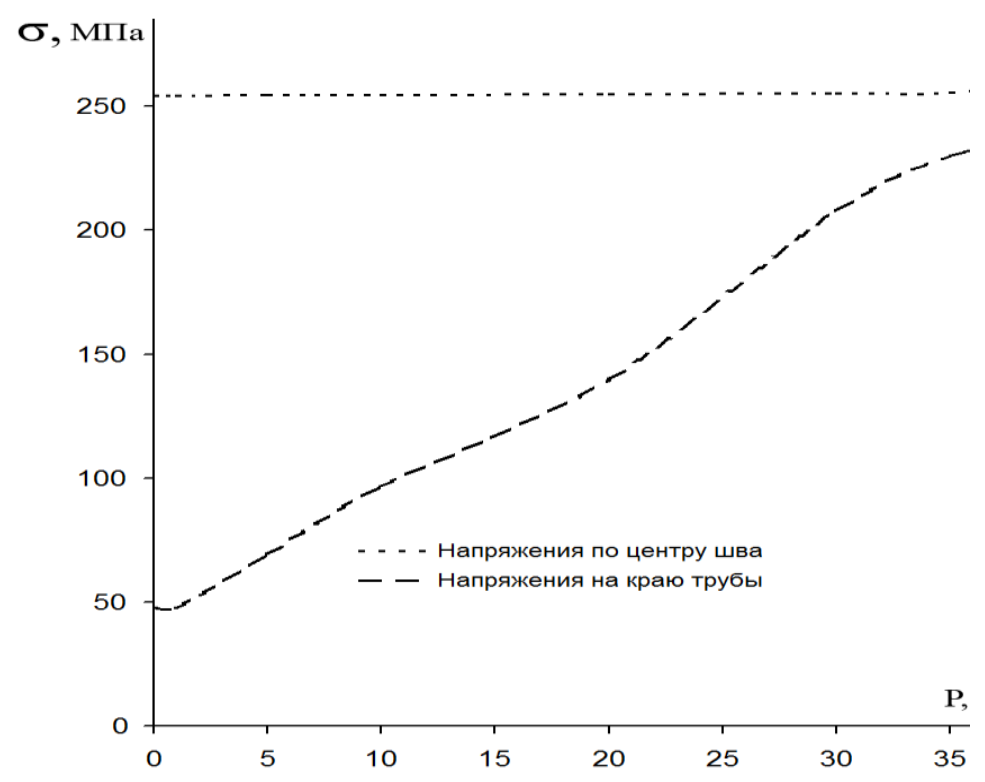

Fig. 5. Allocation of the stresses in the tube 


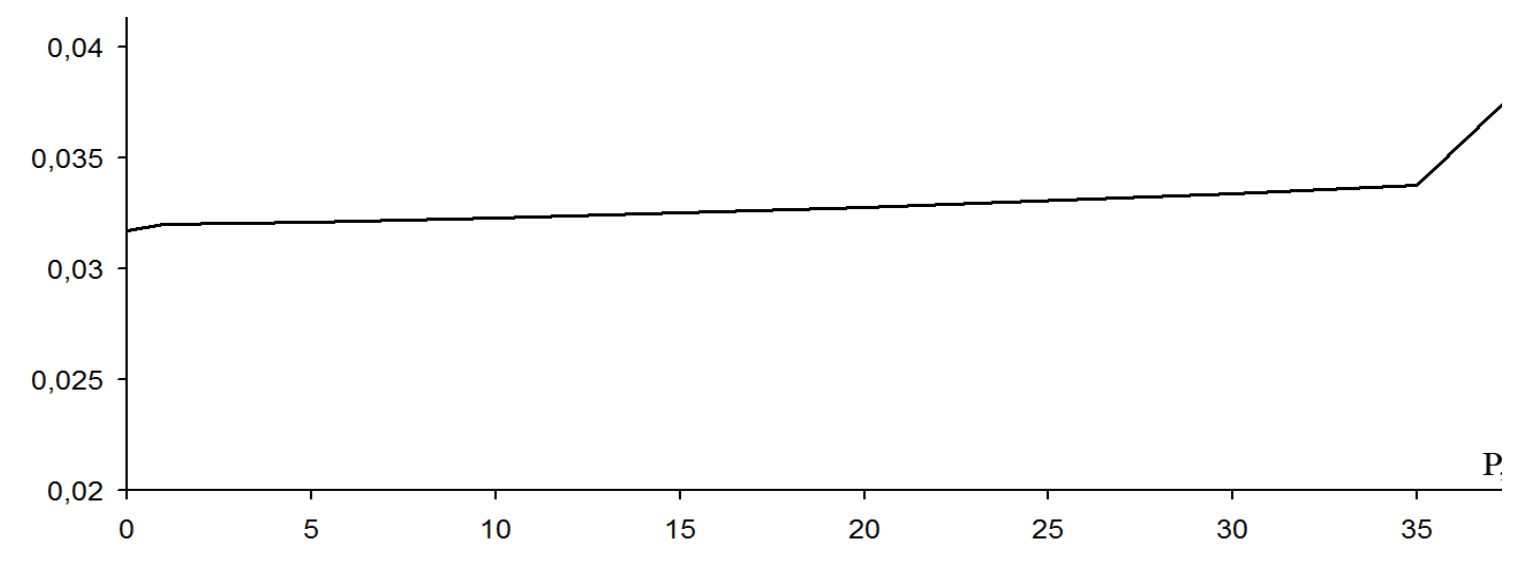

Fig. 6. The changes in plastic deformation in the weld seam

The temperature stresses (Fig. 5) for this task exceed the yield point. The maximum values are in the weld zone on the inner surface of the pipe and below the surface at the outer diameter of the pipe at bending points where the weld seam is joint with the base metal. Stresses in the center of the weld seam begin to grow only when the stresses in the base material are approaching the yield point. Plastic deformation (Fig. 6) in the weld seam begins to grow with increasing stresses in the weld seam.

\section{Conclusions}

The paper presents an algorithm for calculating the stress-strain state of a welded pipeline connection. It's shown that the stresses and plastic deformation growing in the welded joint is observed only when the material of the pipe begins to pass into the plastic region far from the welded seam. In addition, the residual stresses are greater than the yield point.

\section{References}

1. Яхно Б. О. Розрахунок зварних з'єднань з використанням програмного комплексу Abaqus [Електронний ресурс]: методичні вказівки до виконання комп'ютерного практикуму 3 дисципліни «Інженернонаукові обчислювальні комплекси» для всіх форм навчання зварювального факультету / Б. О. Яхно, С. І. Трубачев ; НТУУ «КПІ». Електронні текстові дані (1 файл: 3,81 Мбайт). - Київ : НТУУ «КПІ», 2013. - 64 с. - Режим доступу: http://ela.kpi.ua/handle/123456789/6239 ISBN: 978-617-7021-08-6.

2. Trubachev $S$. I. The calculation of the stress-strain state of the front landing gear transport aircraft / S. I. Trubachev, O. N. Alekseychuk // Інформаційні системи, механіка та керування: науково-технічний збірник. - 2014. Вип. 11. - С. 88-91. Режим доступу: http://ela.kpi.ua/handle/123456789/17642. 
3. Трубачев С. І. Розрахунок циліндричних товстостінних оболонок з отворами / С. І. Трубачев, О. М. Алексейчук // Механіка гіроскопічних систем: науково-технічний збірник. - 2014. - Вип. 28. - С. 125-130. Режим доступу: http://ela.kpi.ua/handle/123456789/17423. 